\title{
PERFORMANCE OF NEW PROMISING GENOTYPES OF WHEAT UNDER DIFFERENT NITROGEN AND SALINITY LEVELS OF IRRIGATION WATER \\ Salem, A.K.M. ${ }^{* * *}$ and A.A. Al-Doss* \\ Plant Production Department, College of Food and Agriculture Sciences, King Saud University, Riyadh, Kingdom Saudi Arabia. \\ ** Department of Field Crops Research, National Research Center, Giza, Egypt. \\ Correspondence: aksalem@ksu.edu.sa
}

\begin{abstract}
Plant growth and yield of wheat crop in saline soils and water may be increased by optimum fertilization management. The aim of this study was to investigate the response of new promising wheat genotypes to various nitrogen levels under various irrigation water salinity levels. To achieve this aim two experiments were conducted at the Experimental Farm of Dierab Station, Faculty of Agriculture and Food Sciences, King Saud University, Riyadh city, Kingdom Saudi Arabia during 2008/2009 and 2009/ 2010 seasons. The experiment was laid out in strip-split plot design with three replications. The vertical plots were allocated with three salinity levels of irrigation water $(1000,2000$ and $4000 \mathrm{ppm})$. The horizontal plots were assigned to three nitrogen levels $(100,200$ and $300 \mathrm{~kg} \mathrm{~N} / \mathrm{ha})$. While, the sub-plots were devoted to seven genotypes (KSU 101, KSU 102, KSU 104, KSU 105, KSU106 and Youkora Rojo)

The main results could be summarized as follows; the salinity levels significantly affected the yield and yield components of wheat whereas, they were significantly decreased as salinity level was increased up to $1000 \mathrm{ppm}$. The optimum nitrogen rate was $200 \mathrm{~kg} \mathrm{~N} / \mathrm{ha}$. The new released genotypes showed superiority against the commercial variety i.e. Youkora Rojo under normal and salinity conditions. The best released genotype was KSU102 followed by KSU 101 and KSU103.

Increasing nitrogen rate at high salinity level of irrigation water is not favorable, whereas it significantly decreased wheat grain yield and main yield components. By the way, $200 \mathrm{~kg} \mathrm{~N} / \mathrm{ha}$ was the optimum under salinity conditions. The new tested wheat variety confirmed its salinity tolerance rather than common American variety.

It can be concluded that, fertilizing wheat genotype KSU102 with $200 \mathrm{~kg}$ $\mathrm{N} / \mathrm{ha}$ could be recommend to maximizing wheat productivity under salinity conditions.
\end{abstract}

\section{INTRODUCTION}

The wheat crop is the most important strategic crops in the Saudi Arabia Kingdom, where the cultivated area is around 483861 ha produced about 2,057,471 tones (Ministry of Agriculture - Statistical Book, $1426 \mathrm{~h}$ and 2005).

Salinity and poor quality water are the main environmental constrains for agriculture production with some focusing on wheat production in Saudi. Patel et al. (2003) and Kaledhonkar and Keshari (2006) stated that the yield and yield components of wheat were significantly decreased by increasing salinity level of irrigation water.

Nitrogen is often the most important plant nutrients. Wheat is very sensitive to insufficient nitrogen and very responsive to nitrogen fertilization (David et al., 2005). Many workers all over the world concluded that using 
nitrogen fertilizer in suitable needed rates could improve growth, yield and its components as well as quality of wheat i.e. Sayed et al. (2003), Tammam and Tawfils (2004), Allam (2005), Seadh and Badawi (2006), Ibrahim (2007), Mekhemar (2008) and Seadh et al. (2009).

Chosen the high yielding ability genotypes undoubtedly is very important to raise wheat productivity per unit area. It is known that using only one wheat variety in different environmental conditions such as Saudi Arabia's resulted in to low productivity. The cultivar Youkora Rojo is the dominant cultivar in Kingdom Saudi Arabia since 1982, which occupying about $90 \%$ of the cultivated area of wheat. Youkora Rojo wheat variety is high yielding cultivar, but it is unstable due to high sensitivity to changes in the environmental factors such as salinity. As the average year find that the rate of production of wheat variety Youkora Rojo in the Kingdom's regions ranged from 3.1 tons / ha in Abha, Asir Region and to 7.1 tons / ha in the Hail region, which represents an economic waste due to poor varietal policy for each region (Ministry of Agriculture, 1422 and 2001). Recent studies conducted on the improved and selected some new genotypes Saudia Arabia Kingdom, have shown that the superiority of some strains on the trade variety of Youkora Rojo such as strains KSU 102, KSU 105 and KSU 106 which significantly exceeded it by more than 30\% (Moustafa et al., 1998 and AlDoss et al., 2004). Furthermore, other studies have shown the superiority of some newly produced straiNS in the growth and production under conditions of moisture and soil salinity stress (Alderfasi and Moustafa, 2001) which bodes well for the ability of these strains resistant to different environmental conditions in the Kingdom. Mohammad et al. (2008) and Yildirim and Bahar (2010) found great genetic variation between different wheat genotypes tested under various salinity levels regarding the yield and yield components of wheat crop.

In saline soils, the proper use of $\mathrm{N}$ fertilizer particularly, the rate in which $\mathrm{N}$ is applied to salt-stressed plants may influence plant-nutrient-salinity relationships (Martinez and Cerda, 1989 and Traore and Maranville, 1999). El-Gharably et al. (2010) stated that dry weights of shoot and root were reduced by salinity in all $\mathrm{N}$ treatments. Addition of $\mathrm{N}$ significantly increased shoot and root dry weights with significant differences between $\mathrm{N}$ and rates. Furthermore, under non-saline conditions, addition of $\mathrm{NO}_{3}-\mathrm{N}$ at rates higher than N50 had a negative effect, while N100 increased shoot and root dry weights. Addition of greater than N50 increased soil salinity and reduced micronutrient uptake both of which likely limited plant growth (Ali et al., 2001 and Irshad et al., 2002). Under saline soil, Mahmood and Kaiser (2003) and Asghar et al., (1996) found that application of $100 \mathrm{~kg} \mathrm{~N}$ ha' proved to be the most "suitable one. This was attributed to a significant increase in tillering, spike length. 100-grain weight and grain yield per plant. However, at the highest levels of salinity $\left(15 \mathrm{dSm}^{-1}\right)$ while the application of $150 \mathrm{Kg} \mathrm{N} / \mathrm{ha}$ significantly reduced the above-mentioned traits. El-Gharably (2011) found that growth and yield of wheat crop were significantly responded to nitrogen rate to $50 \mathrm{~g} / \mathrm{kg}$ under higher salinity level and increasing $\mathrm{N}$ beyond that level reduced the yield of wheat. 
Developing proper culture practices such as crop programs fertilization occasion, will help to increase productivity in the wheat. Yecora Rojo promoted to local conditions, was significantly responded to nitrogen from $200 \mathrm{~kg}$ to $400 \mathrm{~kg} \mathrm{~N} / \mathrm{ha}$. With this increase in nitrogen fertilization, most farmers do not observe in the relation between level of nitrogen fertilization and the salt concentration of irrigation water as well as the soil salinity which increasing fertilizer and wheat productivity shown that by Kafafi (1984), Feigin (1985) and Ahmed et al. (1993).

Therefore, this investigation was established to investigate the response of some new promising genotypes of wheat irrigated by different saline water levels to various nitrogen levels under the environmental conditions of Riyadh, Kingdom Saudi Arabia.

\section{MATERIAL AND METHODS}

The field experiments were conducted at the Experimental Farm of Dierab Station, Faculty of Agriculture and Food Sciences, King Saud University, Riyadh city, Kingdom Saudi Arabia during 2008/2009 and 2009/2010 seasons to study the response of new promising wheat genotypes to various nitrogen levels under various water salinity levels.

A strip-split plot design with three replications was used in this study. The vertical plots were assigned to three salinity levels of irrigation water; A) fresh water with salinity level of $1000 \mathrm{ppm}, \mathrm{B})$ moderate saline water with salinity level of $2000 \mathrm{ppm}$ and C) high saline water with salinity level of 4000 $\mathrm{ppm}$. The horizontal plots were devoted to three nitrogen levels (100, 200 and $300 \mathrm{~kg} \mathrm{~N} / \mathrm{ha}$ ). Meanwhile, the new tested wheat genotypes as shown in Table 1 were arranged in the sub-plots.

Table 1: The wheat genotypes used in the current experiment.

\begin{tabular}{|l|c|c|c|}
\hline Number & Variety & Generation & Source \\
\hline 1 & KSU101 & L1199-3 & Plant production department \\
\hline 3 & KSU102 & L1199-5 & Plant production department \\
\hline 4 & KSU103 & L1199-6 & Plant production department \\
\hline 5 & KSU104 & L1199-9 & Plant production department \\
\hline 6 & KSU105 & L1199-15 & Plant production department \\
\hline 7 & KSU106 & L1199-16 & Plant production department \\
\hline
\end{tabular}

Each experimental unit area was $2 \times 3 \mathrm{~m}$ occupying an area of $6 \mathrm{~m}^{2}$. The soil was sandy in texture. The experimental field was well prepared through ploughings, compaction and then divided into the experimental units with dimensions as previously mentioned. Calcium super phosphate $(15.5 \%$ $\mathrm{P}_{2} \mathrm{O}_{5}$ ) was applied during soil preparation (after ploughing and before division) at the rate of $350 \mathrm{~kg} / \mathrm{ha}$.

Wheat seeds at the rate of $200 \mathrm{~kg} / \mathrm{ha}$ were drilled in rows with space of $20 \mathrm{~cm}$ between rows. Irrigation was applied using the water kept in tanks in which the determined concentrations of salt were prepared. The nitrogen fertilizer in the form of urea $(45.0 \% \mathrm{~N})$ was applied as formerly mentioned levels as top dressing in four equal doses before the first fourth irrigations. Magnesium sulphate was applied at the rate of $20 \mathrm{~kg} / \mathrm{ha}$ in two equal doses; 
at 50 and 75 days after sowing. In addition, microelements were added at the rate of $3 \mathrm{~kg} / \mathrm{ha}$ in two splits after 35 and 50 days from sowing. The common agricultural practices for growing wheat according to the recommendations of Ministry of Agriculture were followed, except the factors under study.

At harvesting, ten spikes were randomly picked up from each subplot to determine the yield attributing characteristics; number of spikes $/ \mathrm{m}^{2}$ and 1000-grain weight $(\mathrm{g})$. The sex inner rows of each sub-plots were harvested, dried, threshed and the grain and biological yield were assessed at $14 \%$ moisture content, and converted per hectare.

All data were statistically analyzed according to the technique of analysis of variance (ANOVA) for the strip split - plot design as published by Gomez and Gomez (1984) by means of "MSTAT-C" Computer software package. Least significant of difference (LSD) method was used to test the differences between treatment means at $5 \%$ level of probability as described by Snedecor and Cochran (1980).

\section{RESULTS AND DISCUSSION}

Data in Table 2 show no significant effect to the years on 1000grain weight and grain yield. The differences were significant for number of spikes $/ \mathrm{m}^{2}$ and biological yield. The salinity levels of irrigation water had highly significant effects on number of spikes $/ \mathrm{m}^{2}, 1000$-grain weight grain and biological yields. However, nitrogen fertilizer levels induced significant differences only in grain yield.

Table 2: Analyses variance of the effect of water salinity levels and nitrogen fertilizer levels on wheat genotypes.

\begin{tabular}{|c|c|c|c|c|c|}
\hline SS & D.F. & $\begin{array}{l}\text { Number of } \\
\text { spikes } / \mathrm{m}^{2}\end{array}$ & $\begin{array}{l}\text { 1000-grain } \\
\text { weight }(g)\end{array}$ & $\begin{array}{l}\text { Grain yield } \\
\text { (t/ha) }\end{array}$ & $\begin{array}{l}\text { Biological yield } \\
\text { (t/ha) }\end{array}$ \\
\hline Years & 1 & 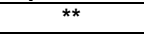 & NS & NS & $\star \star *$ \\
\hline Water salinity levels & 2 & ** &  & ** & ** \\
\hline Water salinity levels $x$ years & 2 & NS & * & NS & NS \\
\hline N-levels & 2 & NS & NS & ${ }^{*}$ & NS \\
\hline $\mathrm{N}$-levels $\mathrm{x}$ years & 2 & ${ }^{*}$ & NS & NS & ${ }^{*}$ \\
\hline $\mathrm{N}$-levels $\mathrm{x}$ water salinity levels & 4 & NS & $\star \star \star$ & $\star \star *$ & NS \\
\hline Genotypes & 6 & $\star *$ & 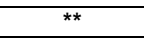 & ** & ${ }^{*}$ \\
\hline Genotypes $\mathrm{x}$ years & 6 & ** & * & ** & ** \\
\hline Genotypes $\mathrm{x}$ water salinity levels & 12 & * & * & ** & * \\
\hline Genotypes x N-levels & 12 & ** & NS & ** & * \\
\hline $\begin{array}{l}\text { Genotypes } x \text { water salinity levels } x \\
\text { years }\end{array}$ & 12 & $\star *$ & NS & ** & NS \\
\hline Genotype x N-levels $\times$ years & 12 & NS & NS & NS & NS \\
\hline $\begin{array}{l}\text { Genotype } \times \text { N-levels } \times \text { water salinity } \\
\text { levels }\end{array}$ & 24 & NS & NS & NS & NS \\
\hline $\begin{array}{l}\text { Genotype } \times \text { water salinity levels } \times N \text { - } \\
\text { levels } \times \text { years }\end{array}$ & 48 & NS & NS & NS & NS \\
\hline
\end{tabular}

Genotypes exhibited highly significant differences concerning number of spikes $/ \mathrm{m}^{2}, 1000$ - grain weight, grain and biological yields. The interaction between genotypes and water salinity levels had a significant effect on number of spikes/ $\mathrm{m}^{2}$ and grain yield, but the interaction effect was insignificant regarding 1000-grain weight and biological yield. The interaction between genotypes and nitrogen fertilizer levels had highly significant effect on number of spikes $/ \mathrm{m}^{2}$ and 1000 -grain weight. The triple interaction among genotypes, nitrogen fertilizer levels and years had insignificant effect on all 
studied characters. Also, the triple interaction among genotypes, water salinity levels and nitrogen fertilizer levels had insignificant effect on number of spikes $/ \mathrm{m}^{2}, 1000$-grain weight, grain and biological yields. Furthermore, the interaction among years, water salinity levels, nitrogen fertilizer levels and genotypes had insignificant effects on 1000- grain weight, grain and biological yields.

Data in Table 3 revealed that no significant differences in wheat grain yield were exerted by fresh irrigation water and irrigation water of $2000 \mathrm{ppm}$ with 7.04 and $6.82 \mathrm{t} / \mathrm{ha}$, respectively. However, use of irrigation water with salinity level of $4000 \mathrm{ppm}$ significantly reduced the wheat grain yield which recorded $5.88 \mathrm{t} / \mathrm{ha}$ under this high salinity level. This indicated that the wheat grain yield was reduced significantly by high salt content in irrigation water. The high salinity level of irrigation water might accumulated more salts in soil resulted high salinity levels in the soil, which suppressed the wheat growth, dry matter production, yield components leading to lower grain yield. This should be considered in irrigating wheat, and the growers and agricultural companies should assess the salinity level of irrigation water before cultivating wheat for using suitable genotype and optimum nitrogen fertilizer program particularly nitrogen fertilizer for seeking high productivity by avoid reduction in the productivity happened under saline water conduction.

Table 3: Averages of number spikes $/ \mathrm{m}^{2}, 1000$ - grain weight, grain and biological yields as affected water salinity levels as average of both years of study.

\begin{tabular}{|c|c|c|c|c|}
\hline $\begin{array}{l}\text { Water salinity } \\
\text { levels }\end{array}$ & $\begin{array}{l}\text { Number of } \\
\text { spikes } / \mathrm{m}^{2}\end{array}$ & $\begin{array}{l}\text { 1000-grain } \\
\text { weight }(\mathrm{g})\end{array}$ & $\begin{array}{c}\text { Grain yield } \\
\text { (t/ha) }\end{array}$ & $\begin{array}{c}\text { Biological yield } \\
(\mathrm{t} / \mathrm{ha})\end{array}$ \\
\hline Fresh water & $626.03 a$ & $37.13 a$ & $7.04 \mathrm{a}$ & $26.26 \mathrm{a}$ \\
\hline (2000 ppm) & $568.67 \mathrm{~b}$ & $35.51 b$ & $6.82 a$ & $24.43 b$ \\
\hline (4000 ppm) & $512.12 c$ & $28.90 \mathrm{c}$ & $5.88 b$ & $22.22 \mathrm{c}$ \\
\hline L S D at 0.05 & 27.91 & 1.51 & 0.83 & 1.39 \\
\hline
\end{tabular}

Significant differences were recorded in the biological yield, number of spikes $/ \mathrm{m}^{2}$ and 1000 - grain weight by using different levels of salinity in water of irrigation. The biological yield was reduced from 26.26 to $24.43 \mathrm{t} / \mathrm{ha}$ under fresher water and $2000 \mathrm{ppm}$, respectively. Also, number of spikes $/ \mathrm{m}^{2}$ was reduced from 626.03 to 568.67 under using irrigation water with salinity levels of fresh and $2000 \mathrm{ppm}$, respectively. The same trend was found regarding 1000 - grain weight that was reduced from 37.13 to 35.51 and 28.9 $\mathrm{g}$ for fresh water, 2000 and $4000 \mathrm{ppm}$, respectively.

In conclusion, all yield attributes were reduced by using high level of salinity in irrigation water. Similar results were reported by Patel et al. (2003), Kaledhonkar and Keshari (2006), Mohammad et al. (2008) and Yildirim and Bahar (2010).

Data in Table 4 show that the effect of nitrogen fertilizer levels on grain yield and yield attributes as average of both years of study.

The grain yield insignificantly increased from 6.42 to $6.97 \mathrm{t} / \mathrm{ha}$ when the nitrogen fertilization rates increased from $100 \mathrm{~kg}$ to $200 \mathrm{~kg} \mathrm{~N} / \mathrm{ha}$, respectively. The grain yield was significant reduced to $6.34 \mathrm{t} / \mathrm{ha}$ at $300 \mathrm{~kg} \mathrm{~N}$ /ha. This yield reduction could be attributed to high level of fertilization under high salinity level as was indicated by previous studies (Asghar et al., 1996 
and El-Gharably, 2011). The rest of yield attributes did not affect by the tested nitrogen levels in both seasons. Thereby, the recommended nitrogen under saline water is $100 \mathrm{~kg} \mathrm{~N} / \mathrm{ha}$. Thus, high nitrogen level is not recommended under higher salinity level in soil or irrigation water. The current findings are in a good conformity with those reported by Ahmed et al. (1993).

Table 4: Averages of number spikes $/ \mathrm{m}^{2}, 1000$ - grain weight, grain and biological yields as affected nitrogen fertilizer levels as average of both years of study.

\begin{tabular}{|c|c|c|c|c|}
\hline $\begin{array}{l}\text { Nitrogen fertilizer } \\
\text { levels (kg N/ha) }\end{array}$ & $\begin{array}{l}\text { Number of } \\
\text { spikes } / \mathrm{m}^{2}\end{array}$ & $\begin{array}{l}1000 \text {-grain } \\
\text { weight (g) }\end{array}$ & $\begin{array}{l}\text { Grain yield } \\
\text { (t/ha) }\end{array}$ & $\begin{array}{c}\text { Biological yield } \\
\text { (t/ha) }\end{array}$ \\
\hline 100 & $568.10 a$ & $34.19 a$ & $6.42 \mathrm{ab}$ & $24.27 a$ \\
\hline 200 & $575.08 a$ & $34.22 \mathrm{a}$ & $6.97 a$ & $24.85 a$ \\
\hline 300 & $571.27 a$ & $33.15 a$ & $6.34 \mathrm{~b}$ & $24.07 a$ \\
\hline LS D at 0.05 & NS & NS & 0.57 & 0.99 \\
\hline
\end{tabular}

Table 5: Averages of number spikes $/ \mathrm{m}^{2}, 1000$ - grain weight, grain and biological yields as affected by some wheat genotypes as average of both years of study.

\begin{tabular}{|l|c|c|c|c|}
\hline Genotypes & $\begin{array}{c}\text { Number of } \\
\text { spikes } / \mathrm{m}^{2}\end{array}$ & $\begin{array}{c}1000-\text { grain } \\
\text { weight }(\mathrm{g})\end{array}$ & Grain yield (t/ha) & $\begin{array}{c}\text { Biological yield } \\
(\mathrm{t} / \mathrm{ha})\end{array}$ \\
\hline KSU101 & $689.26 \mathrm{a}$ & $26.84 \mathrm{~d}$ & $6.77 \mathrm{bc}$ & $31.24 \mathrm{a}$ \\
\hline KSU102 & $575.56 \mathrm{bc}$ & $38.25 \mathrm{a}$ & $7.52 \mathrm{a}$ & $26.54 \mathrm{~b}$ \\
\hline KSU103 & $569.63 \mathrm{bc}$ & $35.49 \mathrm{~b}$ & $7.08 \mathrm{bc}$ & $24.17 \mathrm{~cd}$ \\
\hline KSU104 & $562.59 \mathrm{bc}$ & $35.00 \mathrm{~b}$ & $6.76 \mathrm{bc}$ & $25.06 \mathrm{bc}$ \\
\hline KSU105 & $590.00 \mathrm{~b}$ & $35.29 \mathrm{~b}$ & $6.83 \mathrm{bc}$ & $25.51 \mathrm{bc}$ \\
\hline KSU106 & $543.33 \mathrm{c}$ & $33.39 \mathrm{c}$ & $6.36 \mathrm{c}$ & $22.68 \mathrm{~d}$ \\
\hline Youkora Rojo & $470.00 \mathrm{~d}$ & $32.71 \mathrm{c}$ & $4.71 \mathrm{~d}$ & $15.61 \mathrm{~h}$ \\
\hline L S D at 0.05 & 39.35 & 1.34 & 0.58 & 1.62 \\
\hline
\end{tabular}

Data in Table 5 indicated that the new promising strains significantly performed better than those obtained by the American variety Youkora Rojo which occupies $90 \%$ of wheat cultivate area in Saudi Arabia. Interestingly, data in Table 5 showed the Superiority of the new strains of KSU102 and KSU 103 over all other strains with productivity of 7.52 and $7.08 \mathrm{t} / \mathrm{ha}$, respectively. This encourages recommending the cultivation of the new elite strains under The Kingdom of Saudi Arabia condition replacing to the common American variety in the Kingdom. Previous studies (Al- Dos et al, 2004) proved the superiority of the new genotypes and it was approved by the General Organization of Silos because of its excellent technological characteristics. The genotypes, KSU101, KSU102 were superior in their biological yield (31.24 \& $26.54 \mathrm{t} / \mathrm{ha}$ ), respectively, and were superior for the number of spikes; 689.26 and $575.56 / \mathrm{m}^{2}$. Also, the genotype KSU102 was superior in 1000- grain weight with $32.84 \mathrm{~g}$ followed by KSU 103 with $35.49 \mathrm{~g}$ as compared by the commercial cultivar, Youkora Rojo with 32.71. Great genetic variations among various genotypes under saline conditions were reported by Al-Doss et al. (2004), Mohammad et al. (2008) and Yildirim and Bahar (2010). 
Data in Table 6 showed the obtained grain yield t/ha as affected by the interaction between tested wheat genotypes and salinity levels of irrigation water.

Table 6: Averages of grain yield as affected the interaction between water salinity levels and wheat genotypes as average of both years of study.

\begin{tabular}{|l|c|c|c|}
\hline Salinity of irrigation water & $\begin{array}{c}\text { Irrigated with } \\
\text { fresh water }\end{array}$ & $\begin{array}{c}\text { Irrigated with } \\
\mathbf{2 0 0 0} \mathbf{~ p m}\end{array}$ & $\begin{array}{c}\text { Irrigated with } \\
\mathbf{4 0 0 0} \mathbf{~ p p m}\end{array}$ \\
\hline Genotypes & 7.30 & 7.15 & 5.87 \\
\hline KSU101 & 7.72 & 8.23 & 6.62 \\
\hline KSU102 & 6.61 & 8.23 & 6.68 \\
\hline KSU103 & 7.16 & 6.9 & 6.18 \\
\hline KSU105 & 7.70 & 6.71 & 6.08 \\
\hline KSU106 & 6.95 & 6.62 & 5.51 \\
\hline Youkora Roj & 5.89 & 4.13 & 4.13 \\
\hline L S D at 0.05 & \multicolumn{3}{|c|}{0.99} \\
\hline
\end{tabular}

The new developed strains significantly performed better under various salinity levels of irrigation water as compared to the American variety. In case of using fresh water all genotypes surpassed the American one with yields of $7.30,7,72,7.16$ and $7.70 \mathrm{t} / \mathrm{ha}$ for KSU101,KSu102, KSU104 and KSU105, respectively, as compared with 5.89 t/ha for the American variety, The differences proved to be significant. The same trend was found in case of $2000 \mathrm{ppm}$ and $4000 \mathrm{ppm}$ salinity levels. From going discussion, it could be recommended that the new genotypes cloud be used even under saline conditions either soil or water Al-Doss et al. (2004), Mohammad et al. (2008) and Yildirim and Bahar(2010) came to similar results.

Data in Table 7 present the obtained wheat yield as influenced by the interaction between salinity levels of irrigation water and nitrogen rates. As previously mentioned the higher nitrogen level is not recommended under higher salinity level which led to significant yield reduction and that was fact with all tested genotypes. This yield reduction due to higher nitrogen level under higher salinity level agree with the finding of Kafaki (1984), Feigin (1985), Ahmed et al. (1993), Mahmood and Kaiser (2003) and El-Gharably et al. (2010).

Table 7: Averages of grain yield as affected the interaction between salinity of irrigation water nitrogen fertilizer levels as average of both years of study.

\begin{tabular}{|l|c|c|c|}
\hline \multirow{2}{*}{ N-levels (kg/ha) } & \multicolumn{3}{|c|}{ Salinity of irrigation water } \\
\cline { 2 - 4 } & Fresh water & $\mathbf{2 0 0 0} \mathbf{~ p p m}$ & $\mathbf{4 0 0 0} \mathbf{~ p p m}$ \\
\hline $\mathbf{1 0 0}$ & 7.60 & .046 & 5.60 \\
\hline $\mathbf{2 0 0}$ & 7.35 & 7.55 & 6.00 \\
\hline $\mathbf{3 0 0}$ & 6.17 & 6.86 & 6.00 \\
\hline L S D at 0.05 & \multicolumn{3}{|c|}{0.98} \\
\hline
\end{tabular}

Data in Table 8 show the variable response of wheat genotypes to different levels of nitrogen fertilizer. At $100 \mathrm{~kg} \mathrm{~N} /$ ha the genotypes, KSU102 gave the highest values of grain yield ( $7.86 \mathrm{t} / \mathrm{ha})$, while, the genotype, 
Youkora Rojo gave the lowest value of grain yield (4.62 t/ha). At $200 \mathrm{~kg} \mathrm{~N}$ /ha, the most yielder genotypes was KSU 104 (8.32 t/ha) followed by KSU $103(7.69 \mathrm{t} / \mathrm{ha})$ and $\mathrm{KSU} 102(7.67 \mathrm{t} / \mathrm{ha})$, while the least yielder one was Youkora Rojo (4.70 t/ha). At $300 \mathrm{~kg} \mathrm{~N} / \mathrm{ha}$, the yield was generally decreased for all tested genotypes. However, KSU102 genotype was the most established one, as it yielded 7.04 t/ha, followed by KSU105 with productivity of $7.02 \mathrm{t} / \mathrm{ha}$. Also, The Youkora Rojo American genotype exhibited the lowest yield (4.83 t/ha). Similar results were reported by Mohammad et al. (2008) and Yildirim and Bahar (2010).

Table 8: Averages of grain yield as affected the interaction between nitrogen fertilizer levels and wheat genotypes as average of both years of study.

\begin{tabular}{|l|c|c|c|}
\hline \multirow{2}{*}{ Genotypes } & \multicolumn{3}{|c|}{ N-levels (kg/ha) } \\
\cline { 2 - 4 } & $\mathbf{1 0 0}$ & $\mathbf{2 0 0}$ & $\mathbf{3 0 0}$ \\
\hline KSU101 & 6.91 & 7.06 & 6.35 \\
\hline KSU102 & 7.86 & 7.67 & 7.04 \\
\hline KSU103 & 6.71 & 7.69 & 6.85 \\
\hline KSU104 & 5.99 & 8.32 & 5.97 \\
\hline KSU105 & 6.45 & 7.02 & 7.02 \\
\hline KSU106 & 6.38 & 6.35 & 6.35 \\
\hline Youkora Rojo & 4.62 & 4.7 & 4.83 \\
\hline L S D at 0.05 & \multicolumn{3}{|c|}{0.99} \\
\hline
\end{tabular}

\section{Conclusions and Recommendations}

Nitrogen fertilizer at the rate of $200 \mathrm{~kg} \mathrm{~N} / \mathrm{ha}$ proved to be the optimum rate for higher wheat yield under tested salinity levels. All new genotypes significantly surpassed the common American genotype Youkora Rojo under all tested levels of nitrogen and salinity. The new genotype of KSU102 was superior to other new released genotypes and Youkora Rojo American genotype by around $37 \%$ even under high salinity level of $1000 \mathrm{ppm}$.

\section{REFERENCES}

Ahmed, I. A. ; R. A. Abo- Elenin and W. E. Ahmed (1993). Interactive effects of salinity and both forms and Levels of nitrogen fertility on growth and yield of Barley. $\mathrm{H}$. Leith and A. Al Masoom (eds): Towards the rational use of high salinity tolerant plants, Proceedings of the first ASWAS conference, December 8-15, 1990 at the United Arab Emirates University, Al Ain, United Arab Emirates,2:121-128.

Alderfasi, A.A. and Kh.A. Moustafa (2001). Evaluation of different stress techniques for selection wheat drought tolerance at post- anthesis stage. J. Agric.Sci. Mansoura Univ., 26(8): 3663-3672.

Al-Doss, A. A. ; Kh. A. Moustafa and M. O. Ghandorh (2004). Performance of newly selected promising lines of wheat under different environments in the Riyadh Region.J. Saudi Soc. for Agric., 2:69-77.

Ali, A. ; T.C. Tucker; T.L. Thompson and M. Salim (2001). Effects of salinity and mixed ammonium and nitrate on the growth and nitrogen utilization of barley. J Agron. Crop Sci., 186:223-228 
Allam, S.A. (2005). Growth and productivity performance of some wheat cultivars under various nitrogen levels. J. Agric. Sci. Mansoura Univ., 30 (4): 1971-1980.

Asghar M. M. and S.H. Shah(1996). Response of wheat to nitrogen application grown under saline soils. Pakistan J. Agri. Sci., 33: 40-43.

David, C. ; M.H. Jeuffroy and J.M. Meynard (2005). Nitrogen management of organic winter wheat Decision-making through model-based explorations. Res. Sust. Sys., Intern. Sci. Conf. on Organic Agric., Adelaide, Australia, Sept. 21-23, 2005.

El-Gharably, A.(2011). Wheat response to combined application of nitrogen and phosphorus in a saline sandy loam soil. Soil Science and Plant Nutrition, 57, (3) :396-402.

El-GharablyA.; P. Marschner and P. Rengasamy(2010). Wheat growth in a saline sandy loam soil as affected by $\mathrm{N}$ form and application rate. Plant Soil, 328:303-312.

Feigin, A. (1985). Fertilization management of crops irrigated with saline water. Plant and Soil,89:285-299.

Gomez, K.N. and A.A. Gomez ( 1984). Statistical procedures for agricultural Research. $2^{\text {nd }} E d .$, John Wiley and Sons .

Ibrahim, M.E.M. (2007). Impact of nitrogen levels on growth and yield of sugar beet intercropped with faba bean and wheat. M. Sc. Thesis, in Agron., Fac. of Agric. Mansoura Univ.

Irshad M. ; T. Honna; A.E. Eneji and S. Yamamoto (2002). Wheat response to nitrogen source under saline conditions. J .Plant Nutr., 25:26032612.

Kafafi, U. (1984). Plant nutrition under saline conditions in: Shainberg and J. Shalhevet (eds). Soil salinity under irrigation processes and management, pp. 319-338, Spinger - verlag, Berlin.

Kaledhonkar M.J. and A.K. Keshari (2006). Modelling the effects of saline water use in agriculture. Irrig Drain,55:177-190.

Mahmood, T. and Kaiser W.M (2003). Growth and solute of the salt-tolerant kallar grass [Leptochloa fusca (L.) Kunth] as affected by nitrogen source. Plant Soil, 252:359-366.

Martinez, V. and A. Cerda (1989). Influence of nitrogen source on rate of $\mathrm{Cl}$, $\mathrm{N}, \mathrm{Na}$ and $\mathrm{K}$ uptake by cucumber seedlings grown in saline conditions. J. Plant Nutr., 12:971-983.

Mekhemar, G.A.A. (2008). Response of wheat (Triticum aestivum L.) to different mineral nitrogen levels and inoculation with N2 - fixing bacteria. J. Agric. Sci. Mansoura Univ., 33 (1): 447-467.

Mohammad, J ,K. ;J. Bakht; I. A. Khalil1;M. Shafi and M. Ibrar(2008). Response of various wheat genotypes to salinity stress sown under different locations. Sarhad J. Agric.,24 (1):21-30.

Moustafa, Kh.A.; M.O. Ghandorah and S.S. Soliman (1998). Field evaluation of F3 and F5 families of bread wheat under heat and drought stress at central region of Saudi Arabia. Alex .J. Agric. Res.,43(3):27-38.

Patel, R.M. S.O. Prasher and P.K. Goel (2003). Brackish water sub-irrigation for vegetables. Irrig Drain 52:121-132 
Sayed, M.A. ; A.M. Osman ; M.A. Aly and M.A. El-Saaddawy (2003). Effect of irrigation water regime and nitrogen levels on two wheat cultivars under sandy soils. The 11th Annual Conf. of Misr Soc. of Agric. Eng., Oct. 2003: 310-318.

Seadh, S.E. ; M.I. El-Abady ; A.M. El-Ghamry and S. Farouk (2009). Influence of micronutrients foliar application and nitrogen fertilization on wheat yield and quality of grain and seed. J. Biol. Sci., 9 (8): 851-858.

Seadh, S.E. and M.A. Badawi (2006). Wheat response to sowing methods and nitrogen fertilizer levels. J. Agric. Sci. Mansoura Univ., 31 (12): 8097-8106.

Tammam, A.M. and M.B. Tawfils (2004). Effect of sowing date and nitrogen fertilizer levels in relation to yield and yield components of durum wheat (Triticum turgidum var. durum ) under Upper Egypt environments. J. Agric. Sci. MaNSoura Univ., 29 (10): 5434-5442.

Traore, A. and J.W. Maranville (1999) Effect of nitrate/ammonium ratios on biomass production, $\mathrm{N}$ accumulation and use efficiency in Sorghums of different origins. J. Plant Nutr., 22:813-825.

Yildirim, M. and B. Bahar (2010). Responses of some wheat genotypes and their F2 progenies to salinity and heat stress. Scientific Research and Essay, 5(13): 1734-1741.

سلوك سلالات جليدة من القمح تحت مستويات مختلفة من النيتروجين والملوحة 


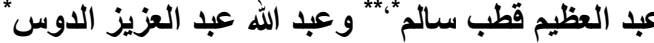

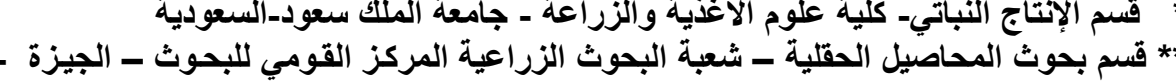
مصر

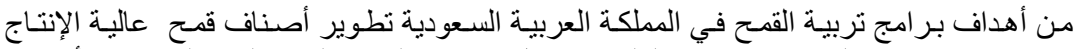

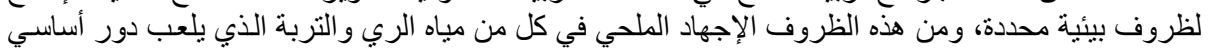

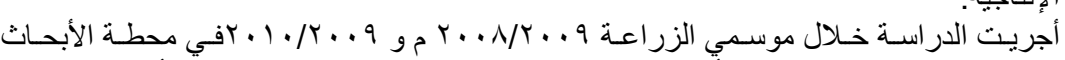

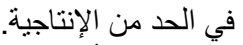

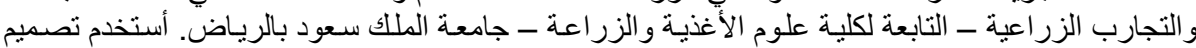

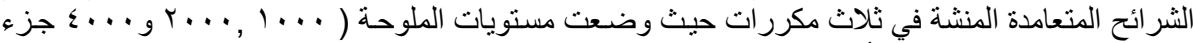

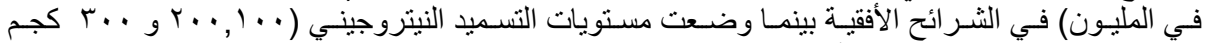

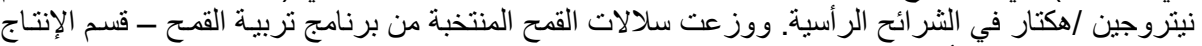

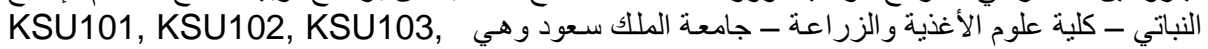
KSU104, KSU105, KSU106 بالإضافة الى صنف القمح المنزرع بالمملكة يو كوراروجو في Kن

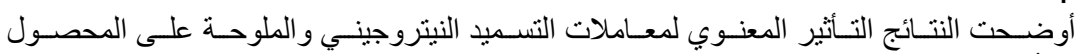

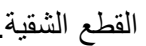

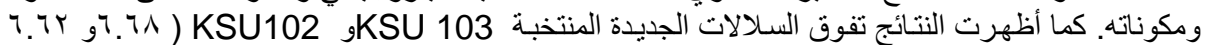

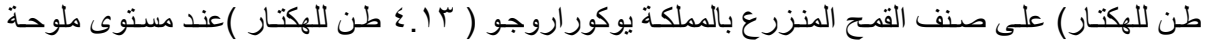

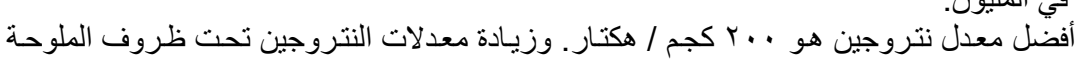

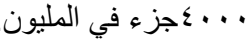



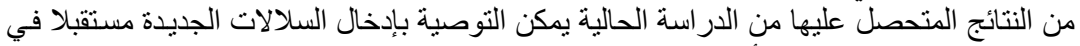

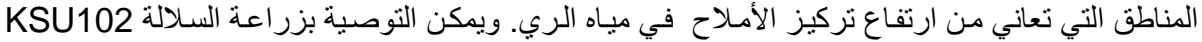

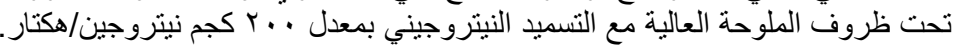

كلية الزراعة - جامعة المنصورة مركز البحوث الزراعية
قام بتحكيم البحث

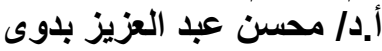

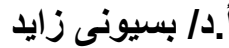

